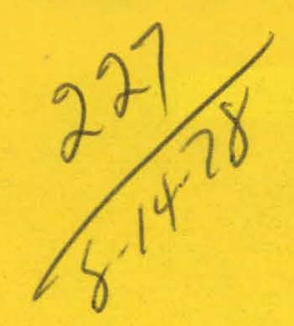

MLM- 2530

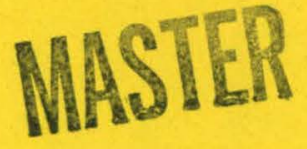

\title{
A Biostratigraphic Analysis of Core Samples from Wells Drilled in the Devonian Shale Interval of the Appalachian and Illinois Basins
}

Stephen J. Martin and Ronald E. Zielinski

July 14, 1978

\section{MOUND FACILITY}

Miamisburg, Ohio

operated by

MONSANTO RESEARCH CORPORATION a subsidiary of Monsanto Company

for the

U. S. DEPARTMENT OF ENERGY

Contract No. EY-76-C-04-0053 


\section{DISCLAIMER}

This report was prepared as an account of work sponsored by an agency of the United States Government. Neither the United States Government nor any agency Thereof, nor any of their employees, makes any warranty, express or implied, or assumes any legal liability or responsibility for the accuracy, completeness, or usefulness of any information, apparatus, product, or process disclosed, or represents that its use would not infringe privately owned rights. Reference herein to any specific commercial product, process, or service by trade name, trademark, manufacturer, or otherwise does not necessarily constitute or imply its endorsement, recommendation, or favoring by the United States Government or any agency thereof. The views and opinions of authors expressed herein do not necessarily state or reflect those of the United States Government or any agency thereof. 


\section{DISCLAIMER}

Portions of this document may be illegible in electronic image products. Images are produced from the best available original document. 
This report was prepared as an account of work sponsored by the United States Government. Neither the United States nor the United States Department of Energy, nor any of their employees, nor any of their contractors, subcontractors, or their employees, makes any warranty, express or implied, or assumes any legal liability or responsibility for the accuracy, completeness or usefulness of any information, apparatus, product or process disclosed, or represents that its use would not infringe privately owned rights.

\section{PRINTED IN THE UNITED STATES OF AMERICA}

Available from

National Technical Information Service

U. S. Department of Commerce 5285 Port Royal Road

Springfield, Virginia 22161

Price: Printed Copy $\$ 4.00$; Microfiche $\$ 3.00$ 


\title{
A Biostratigraphic Analysis of Core Samples from Wells Drilled in the Devonian Shale Interval of the Appalachian and Illinois Basins
}

\author{
Stephen J. Martiri and Ronald E. Zielinski
}

Issued: July 14, 1978

${ }^{*}$ Geochem Research Inc., Houston, Texas

MOUND FACILITY

Miamisburg, Onio 45342
This report was prepared as an account of work sponsored by the United States Government. Neither the United States nor the United States Department of Energy, nor, any of their employees, nor any of their contractors, subcontractors, or their employees, makes any warranty, express or implied, or assumes any legal liability or responsibility for the accuracy, completeness or usefulness of any information, apparatus, product or process disclosed, or represents that its use would not infringo privotoly owned rights.

operated by

MONSANTO RESEARCH CORPORATION

a subsidiary of Monsento Company

for the

U. S. DEPARTMENT OF ENERGY

Contract No. EY-76-C-04-0053 


\section{Contents}

ABSTRACT •. . . . . . . . . . . . . . . . . . . . . . . . . . 3

BIOSTRATIGRAPHY. . . . . . . . . . . . . . . . . . . . . . . . . 3

BIOSTRATIGRAPHY SUMMARY OF THE O-1 WELL. . . . . . . . . . . . . . . . . . . 4

BIOSTRATIGRAPHY SUMMARY OF THE P-1 WELL. . . . . . . . . . . . . . . . . . . 4

BIOSTRATIGRAPHY SUMMARY OF THE KY-2 WELL . . . . . . . . . . . . . . . . . . 9

BIOSTRATIGRAPHY SUMMARY OF THE VA-1 WELI . . . . . . . . . . . . . . . . . . . 9

CONCLUSIONS. . . . . . . . . . . . . . . . . . . . . . . . . . . . . 17

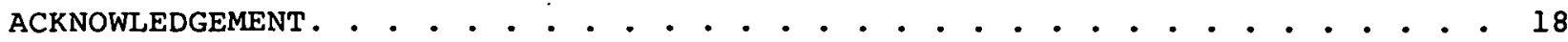

REFERENCES . . . . . . . . . . . . . . . . . . . . . . . . . . 18

BIBLIOGRAPHY • • • • • • • • • • • • • • • • • • • • • • • • • • • • • • • • 18

APPENDIX A

Description of Palynomorphs . . . . . . . . . . . . . . . . . . 20

APPENDIX B

Regional Distribution of Age and Depositional Environments. . . . . . . . 22 


\section{Abstract}

A palynological investigation was performed on 55 samples of core material from four wells drilled in the Devonian Shale interval of the Appalachian and Illinois Basins.

Using a combination of spores and acritarchs, it was possible to divide the Middle Devonian from the Upper Devonian and to make subdivisions within the Middle and Upper Devonian.

The age of the palynomorphs encountered in this study is Upper Devonian.

\section{Biostratigraphy}

A palynological investigation was performed on 55. samples of core material from four wells drilled in the Devonian Shale interval of the Appalachian and Illinois Basins. The following wells were investigated: 0-1 Well, Christian County, Kentucky; P-1 Well, Sullivan County, Indiana; KY-2 Well, Martin County, Kentucky; and VA-1 Well, Wise County, Virginia.

Using a combination of spores and acritarchs, it is possible to divide the Middle Devonian from the Upper Devonian and to make subdivisions within the Middle and Upper Devonian. A major difference between the Middle and upper Devonian is found in the sizes of the spores, as well as in the appearances and disappearances of specific genera and species. In North America, Middle Devonian strata are typified by the spores Rhabdosporites langi (and related species), Calamospora atavata, and other spp. In addition to spores, acritarch taxa are very diagnostic of the boundary between the Middle and Upper Devonian. In the Middle Devonian there are often Duvernaysphaera spp, Polyedryxium spp, and numerous species of. Multiplicisphaeridium spp.
None of the above taxa, however, were observed in the four wells studied here.

Typical Upper Devonian forms were encountered in all four wells. Quisquiletes buchhornensis was found at the base of the $0-1$ and $\mathrm{KY}-2$ Wells (samples 0-1-4 and $\mathrm{KY}-2-66$, respectively). It is known to be present only in Upper Devonian strata.[1]. Also found in the basal parts of some of the studied wells were Multiplicisphaeridium sprucegrovensis, Diexallophasis remotum, Cymatiosphaera peiferi, Maharanites spp, as well as many Ancyrospora species (a diagnostic spore for the Frasnian [2]). The age of the lower strata in the $\mathrm{p}-1$ Well is based on the occurrence of acritarchs $M$. sprucegrovensis, and an unnamed echinate acritarch encountered elsewhere in Frasnian black shales. The age of the basal strata in VA-1 is based on the acritarch taxa $\underline{D}$. remotum and $M$. Sprucegrovensis. The dark spores (indicating a higher thermal maturation and second cycle deposition) in VA-1-27 through VA-1-32 are Middle Devonian (Emsian and Gedinnian), but the acritarchs are definitely of Upper Devonian age as are the lighter colored, less mature (T.A.I.), Ancyrospora-like spores.

Differentiation of the Frasnian and Famennian depends on the disappearance of Ancyrosporalike spores, at the end of the Frasnian, and 
the first appearances of taxa-like Vallatisporites pussilites and $\mathrm{V}$. vallatus. Acritarchs also changed markedly over the boundary. Multiplicisphaeridium-like taxa did not extend into the Famennian; however, Veryhachium spp, Uniellum spp, and Micrhystridium spp become dominant. Very small Cymatiosphaera spp are found in the Famennian, while large Cymatiosphaera species ( $2 x$ to $3 x$ the size of Famennian taxa) were found in the Frasnian. All these taxa were used to obtain the time boundaries in these wells.

Differentiation of the Upper Devonian and Lower Mississippian depends primarily on changes in spores. Acritarch taxa do not change significantly from one unit to the next. The spores seen in the upper strata in the four wells are characteristic of the Upper Devonian (Famennian). The taxa associated with the basal Mississippian, (i.e., Cyrtospora clavigera, Spinozonotriletes uncatus, Endosporites micromanifestus and Knoxisporites literatus) were not found in these wells.

\section{Biostratigraphy summary of the O-1 Well}

The four samples from the $0-1$ Well are Upper Devonian in age. All four contain large amounts of reworked marine algae and small amounts of land derived materials and presumably were deposited under restricted marine conditions.

\section{Age}

Sample 0-1-1 (depth $2184 \mathrm{ft}$ ) was deposited in Upper Devonian (Famennian) time based on several spores. Sample 0-1-3 (depth. $2261 \mathrm{ft}$ ) was deposited in the Upper Devonian because of its stratigraphic occurrence between samples $0-1-1$ and $0-1-4$. There are no diagnostic palynomorphs in sample 0-1-3 which could be used to determine the age. Sample 0-1-4 (depth $2293 \mathrm{ft}$ ) is Upper Devonian (Frasnian) in age based on the occurrences of acritarchs and spores. Sample 0-1-5 (depth $2317 \mathrm{ft}$ ) is Upper Devonian (presumably Frasnian) based on the similarity to 0-1-4. There is insufficient palynomorphs to make a precise age determination.

\section{Environment of deposition}

All four samples were deposited in restricted marine environments. The samples were deposited in an area where reworked and partially degraded marine algae (Tasmanites spp) were redeposited. The absence of abundant "freshly" deposited marine algae indicates that there were restrictions to open maxine conditions.

\section{Biostratigraphy summary of the P-1 Well}

Three samples from the $\mathrm{P}-1$ Well are Upper Devonian in age. The upper part of the section is classified as nonmarine. The restricted marine environment was found in the lower part of the P-l Well.

\section{Age}

Sample $\mathrm{P}-1-1$ (depth $2492 \mathrm{ft}$ ) is Upper Devonian (Famennian) in age based on occurrences of pollen, spores and acritarchs. Sample $\mathrm{P}-1-2$ (depth $2521 \mathrm{ft}$ ) is Upper Devonian (and probably from near the FrasnianFamennian boundary) based on limited palynomorphs and on its stratigraphic position between $\mathrm{P}-1-1$ and $\mathrm{P}-1-3$. Sample $\mathrm{P}-1-3$ (depth $2549 \mathrm{ft}$ ) is Upper Devonian (Frasnian) in age based on the occurrences of acritarchs and spores. 
Table I - AGE

$0-1$ We11

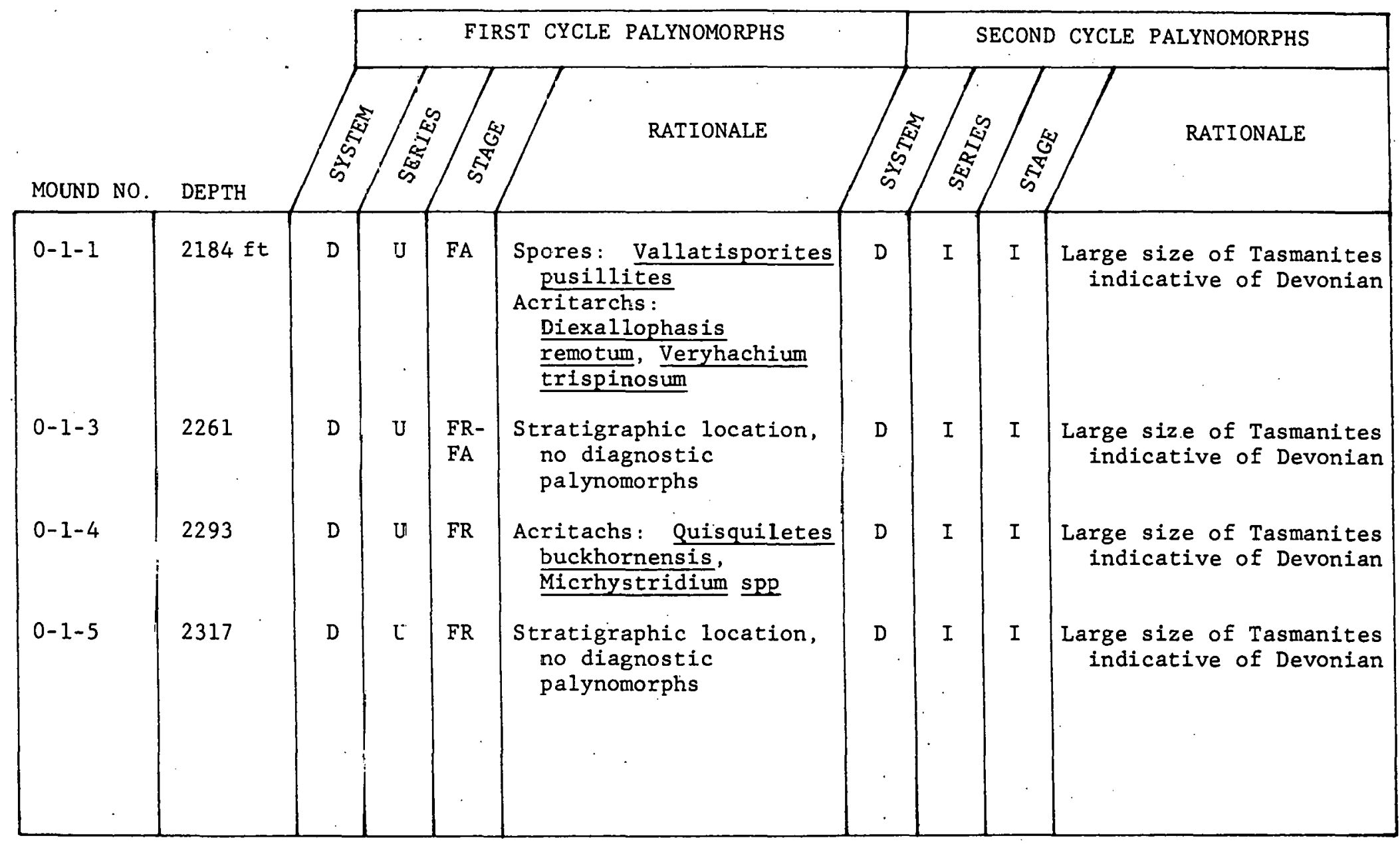

KEY

D Devonian FA Famennian

U Upper FR Frasnian

I Indeterminate 
Table 2 - DEPOSITIONAL ENVIRONMENT AND DISTRIBUTION OF PALYNOMORPHS 0-1 Well

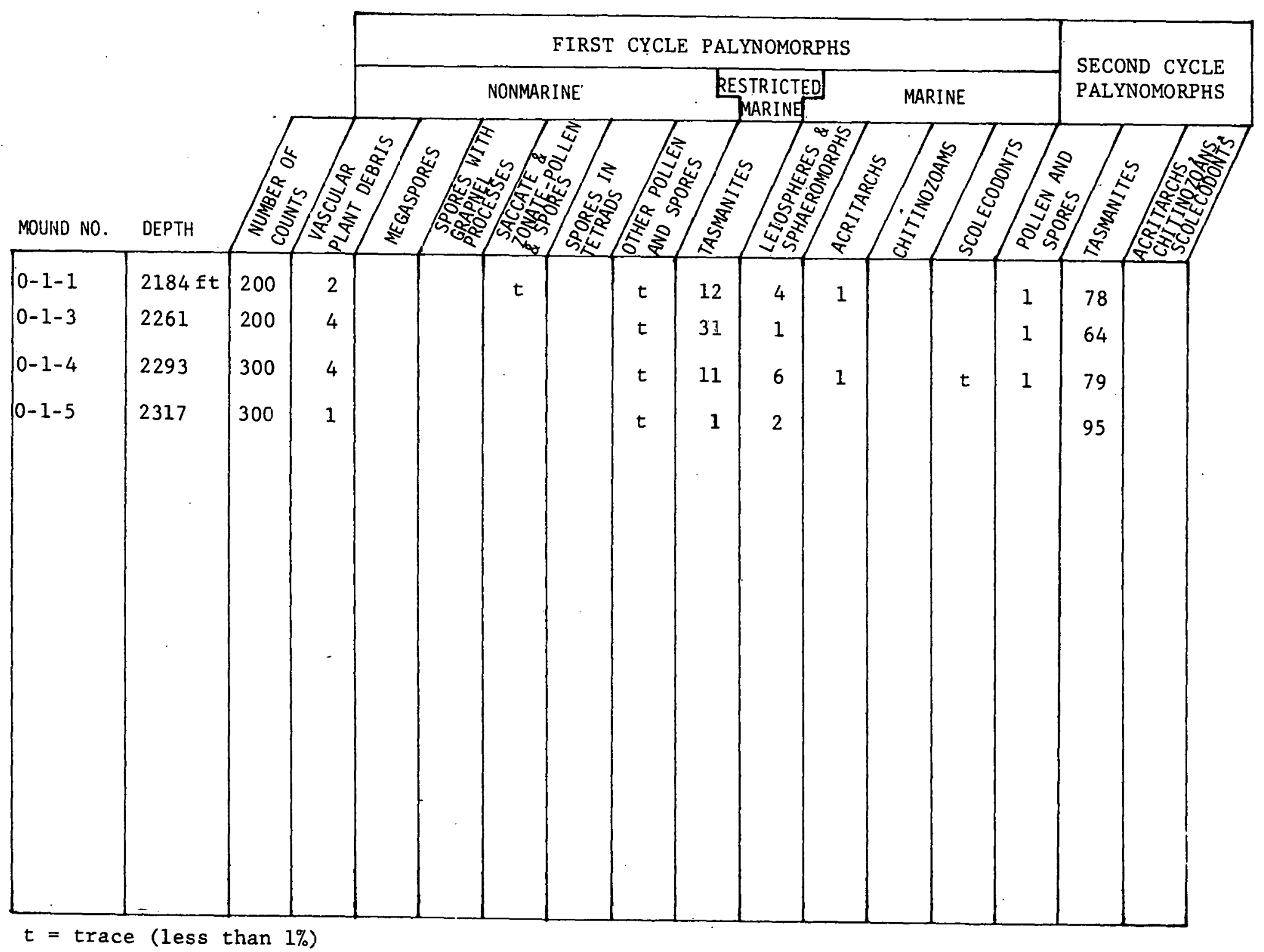


Table 3 - AGE

P-1 Wel1

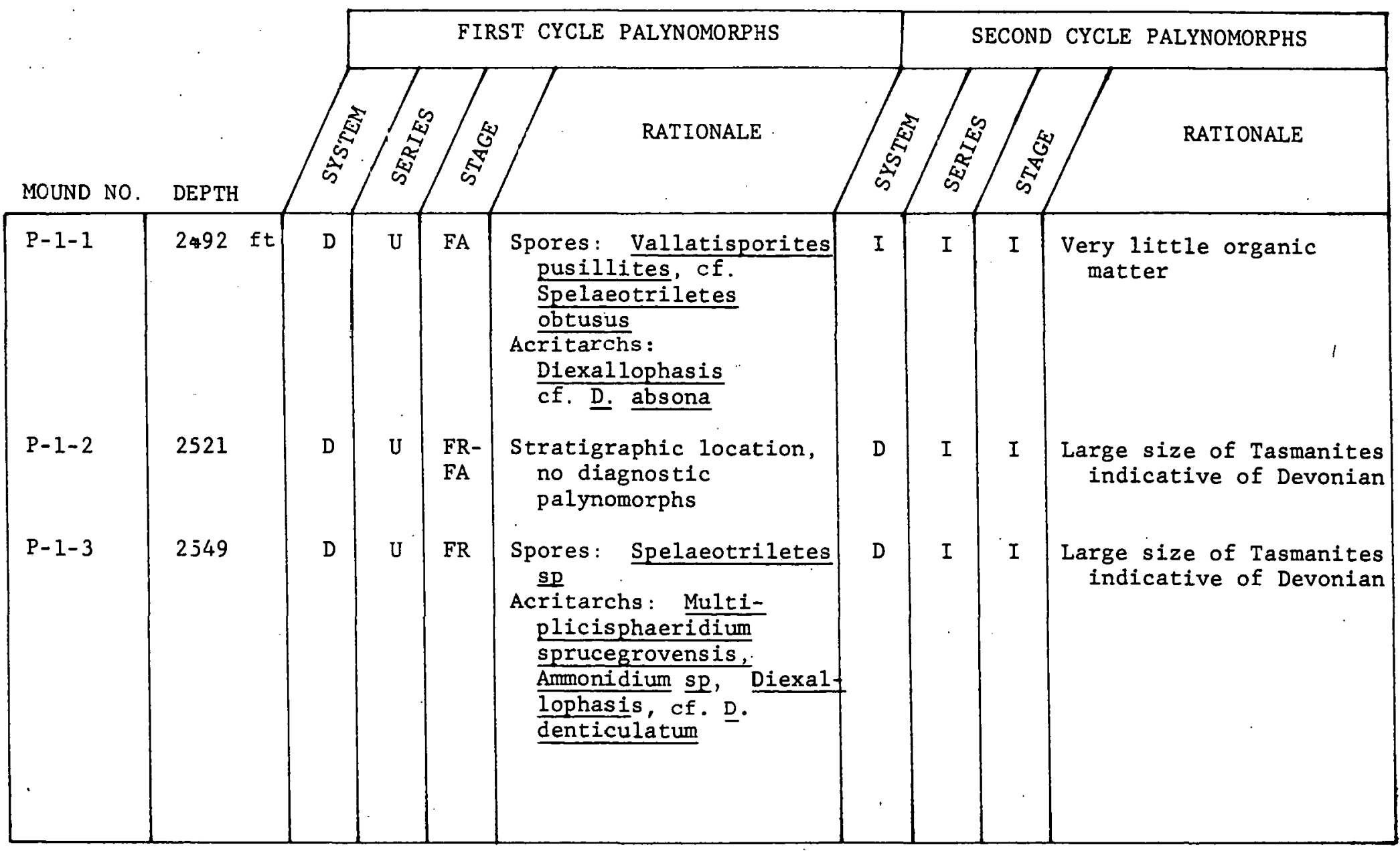

$\begin{array}{llll}\text { KEY } & & & \\ \text { D Devozian } & \text { FA } & \text { Famennian } \\ \text { U Upper } & \text { FR } & \text { Frasnian } \\ \text { I Indeterminate } & & \end{array}$


Table 4 - DEPOSITIONAL ENVIRONMENT AND DISTRIBUTION OF PALYNOMORPHS P-1 Well

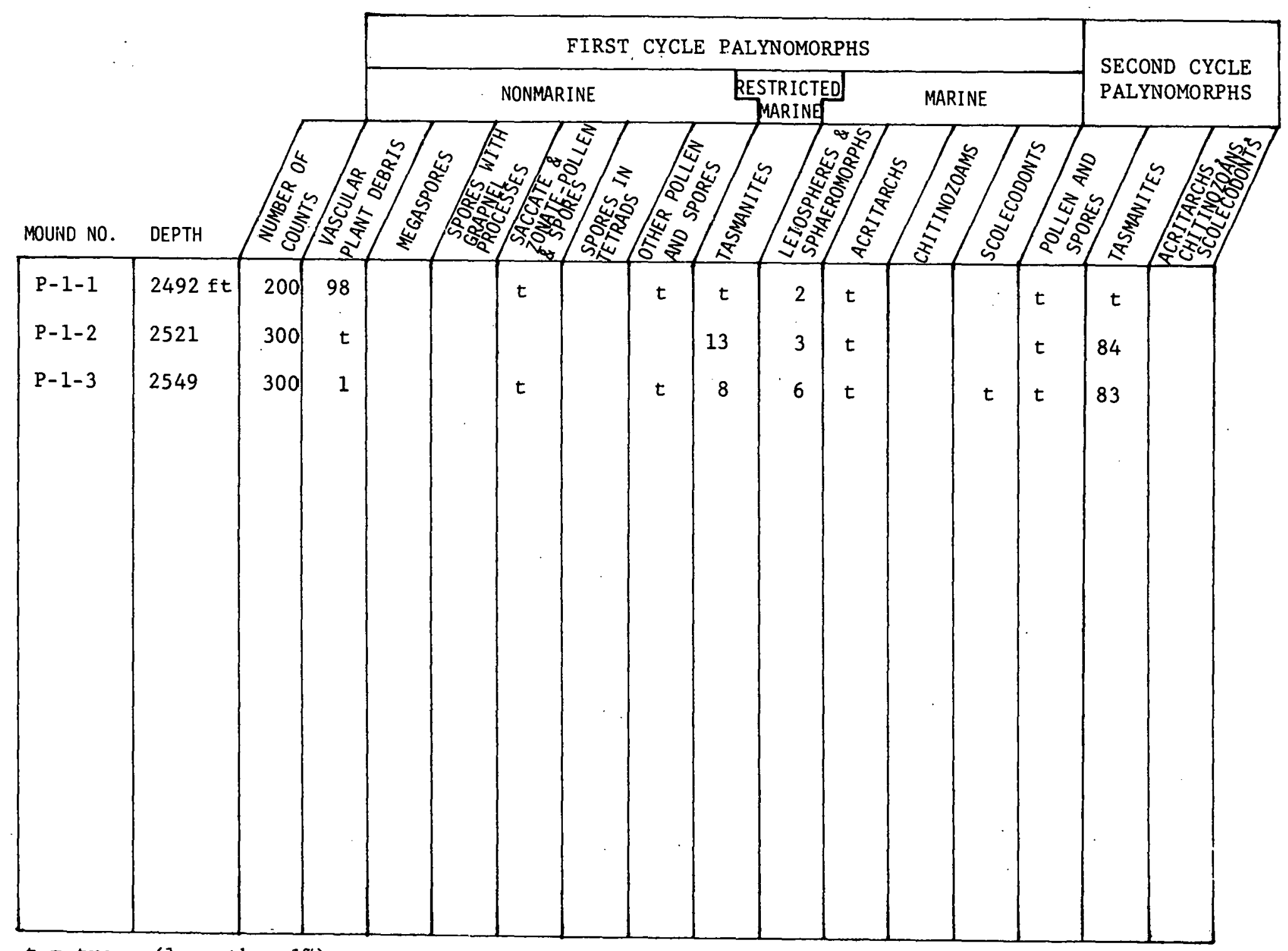

$t=$ trace (less than $1 \%$ ) 


\section{Environment of deposition}

Sample $\mathrm{P}-1-1$ was deposited in a relatively nonmarine environment. The adjacent land mass contributed large amounts of plant material to the sediment. The influence of land-derived organic material is much less in samples. $\mathrm{P}-1-2$ and $\mathrm{P}-1-3$ which are restricted marine deposits. Sample P-1-2 was from a restricted marine environment in which many partially degraded marine algae (Tasmanites spp) accumulated.

Sample P-1-3 was also a site for Tasmanites accumulation.

\section{Biostratigraphy summary of the KY-2 Well}

Thirty-three samples from the KY-2 Well are all Upper Devonian in age. The environmental conditions alternated from a marine environment with diverse phytoplankton productivity, to restricted marine conditions with limited diversity and accomulation of reworked algae, and to nonmarine accumulations of abundant plant debris.

\section{Age}

Samples KY-2-2. to KY-2-47 (depths of 2444 to $3114 \mathrm{ft}$ ) are:Upper Devonian (Famennian) in age, based on the presence of diverse and abundant spores and acritarchs.

Samples $\mathrm{KY}-2-50$ to $\mathrm{KY}-2-66$ (depths of 3144 to $3386 \mathrm{ft}$ ) are Upper Devonian (Frasnian) in age, based on the presence of diverse and abundant spores and pollen.

\section{Environment of deposition}

The environments of deposition shifted continuously throughout the depositional history. Open marine conditions typified by diverse acritarch floras are found in several samples. Phytoplankton productivity was greater in the restricted marine conditions typified by large numbers of Tasmanites in some samples. In other samples, the abundance of vascular plant debris indicated depositional conditions characteristic of a nonmarine environment.

\section{Biostratigraphy summary of the VA-2 Well}

Fifteen samples from the VA-1 Well are Upper Devonian in age. All samples contain large amounts of reworked Lower and Middle Devonian palynomorphs. Except for the deepest sample, the section was predominantly nonmarine.

Age

In sample VA-1-2 (depth $4885 \mathrm{ft}$ ) there is insufficient material to make an age determination. Samples VA-1-4 through VA-1-13 (depths of 4915 to 5229 ft) are all Upper Devonian (Famennian) based on the occurrences of pollen, spores, and acritarchs. There is insufficient material in samples VA-1-15 to $\mathrm{VA}-1-26$ (depths of 5259 to $5393 \mathrm{ft}$ ) to make age determinations. In samples VA-1-27 to VA-1-32 (depths of 5408 to $5469 \mathrm{ft}$ ) the rocks are Upper Devonian (Frasnian) in age, based on the occurrences of acritarchs and spores. In all the samples from the VA-1 We11 there are abundant and diverse reworked and degraded spores and acritarchs from Middle and Lower Devonian aged rocks.

\section{Environment of deposition}

Sample VA-1-32 (depth $5469 \mathrm{ft}$ ) is different from the other fourteen samples in that it was deposited in restricted marine conditions with a minor influx of older plant debris. The succeeding samples VA-1-29 to 


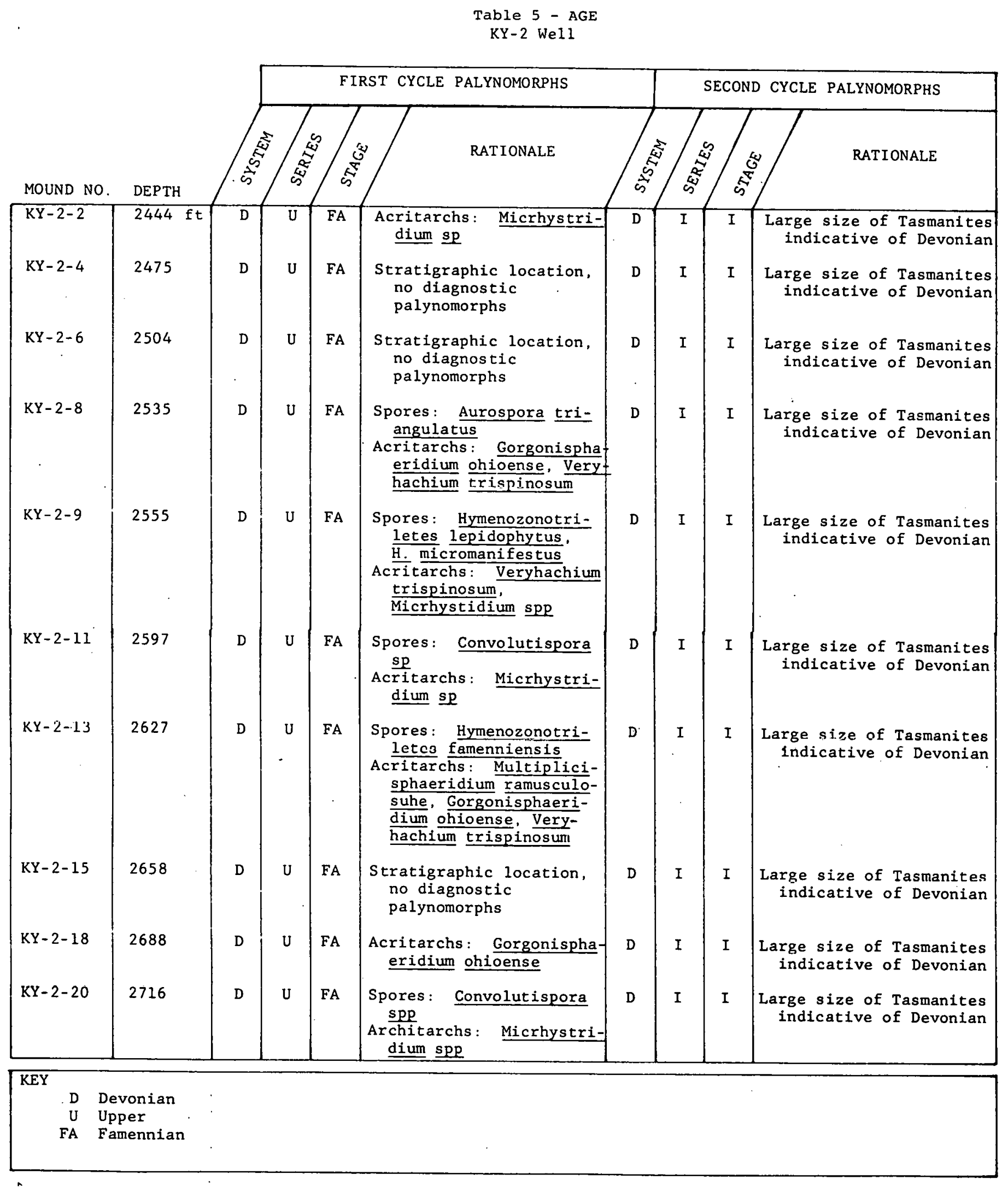


Age

KY-2 Well (Continued)

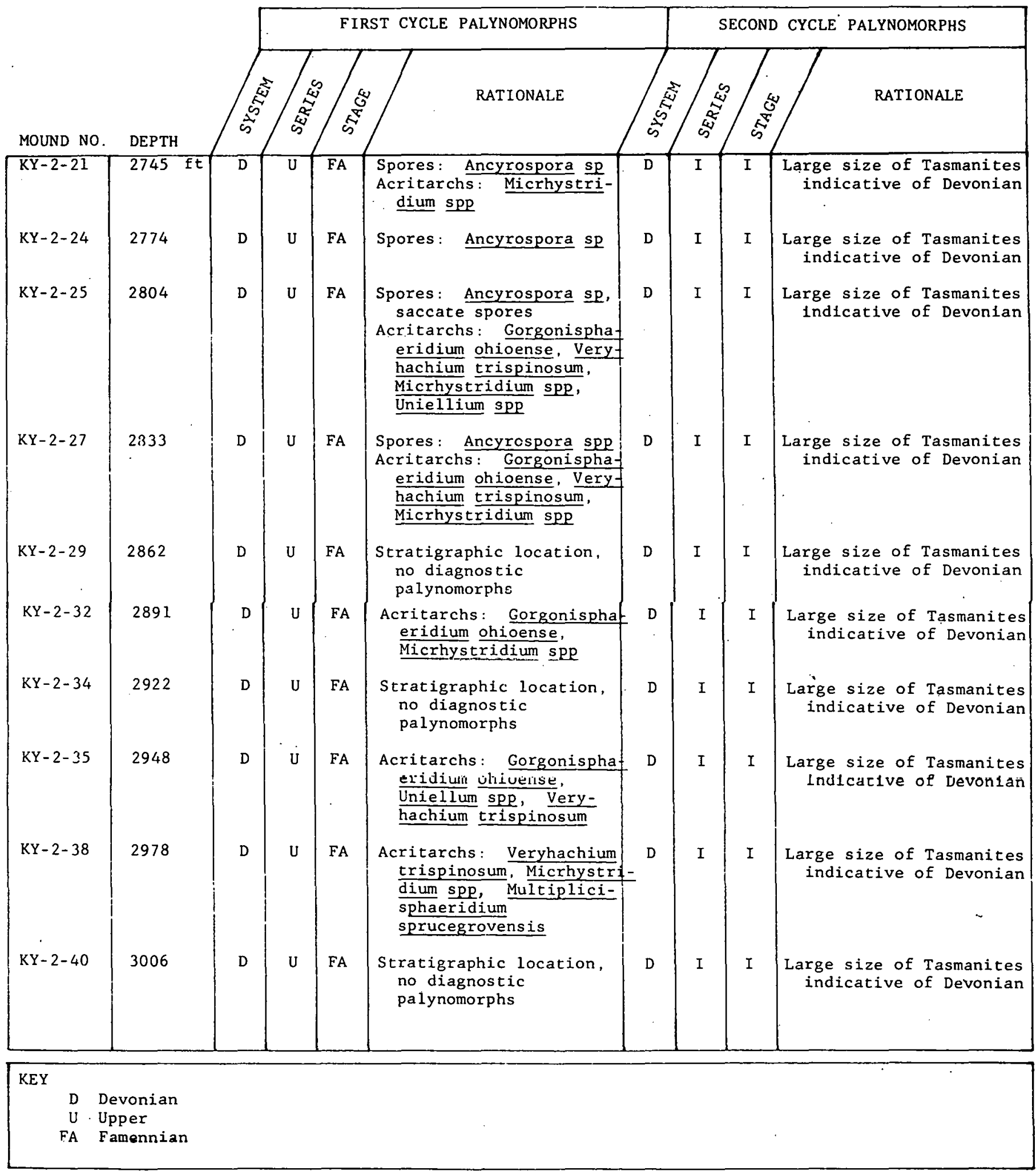




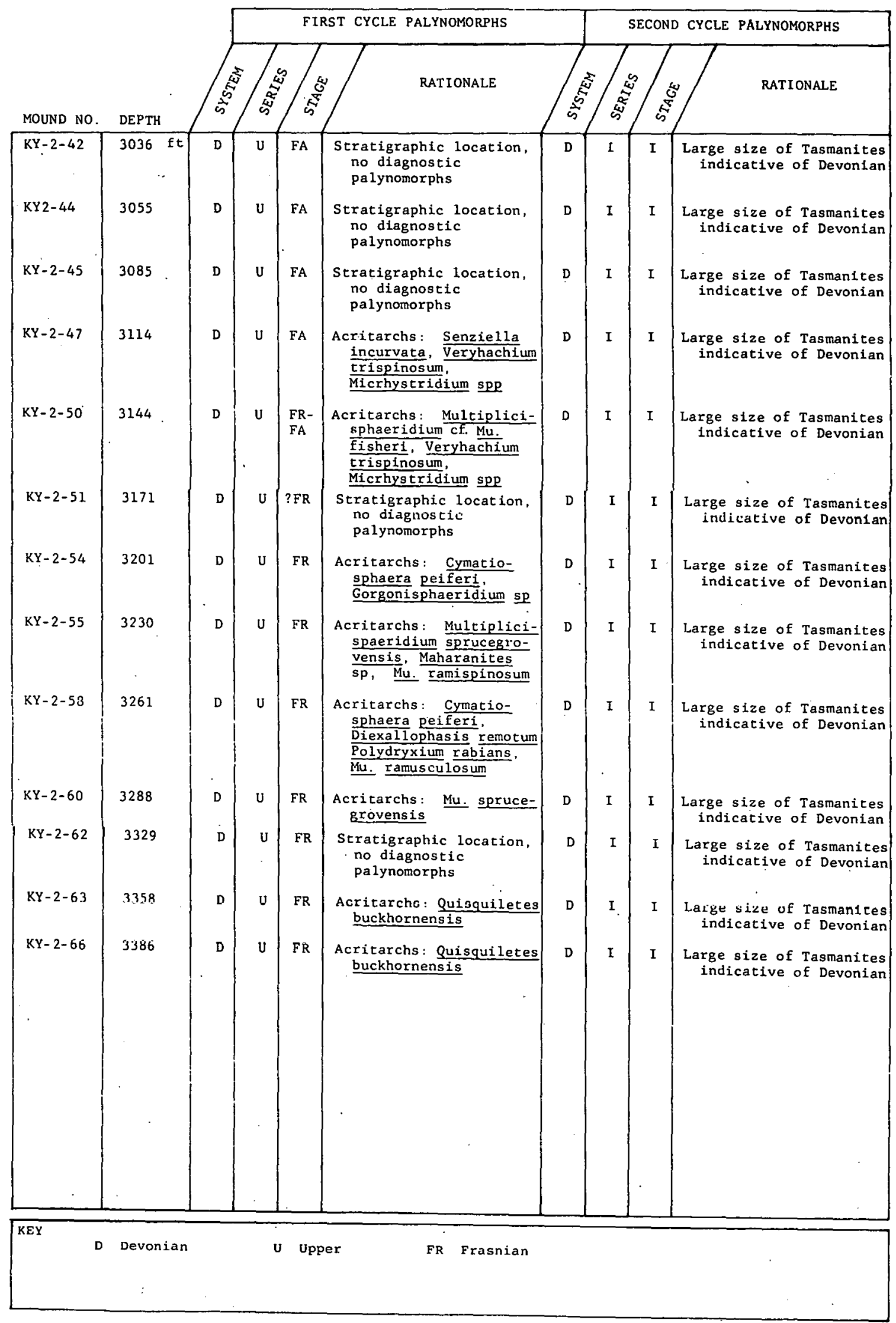


Table 6 - DEPOSITIONAL ENVIRONMENT AND DISTRIBUTION OF PALYNOMORPHS KY-2 Well

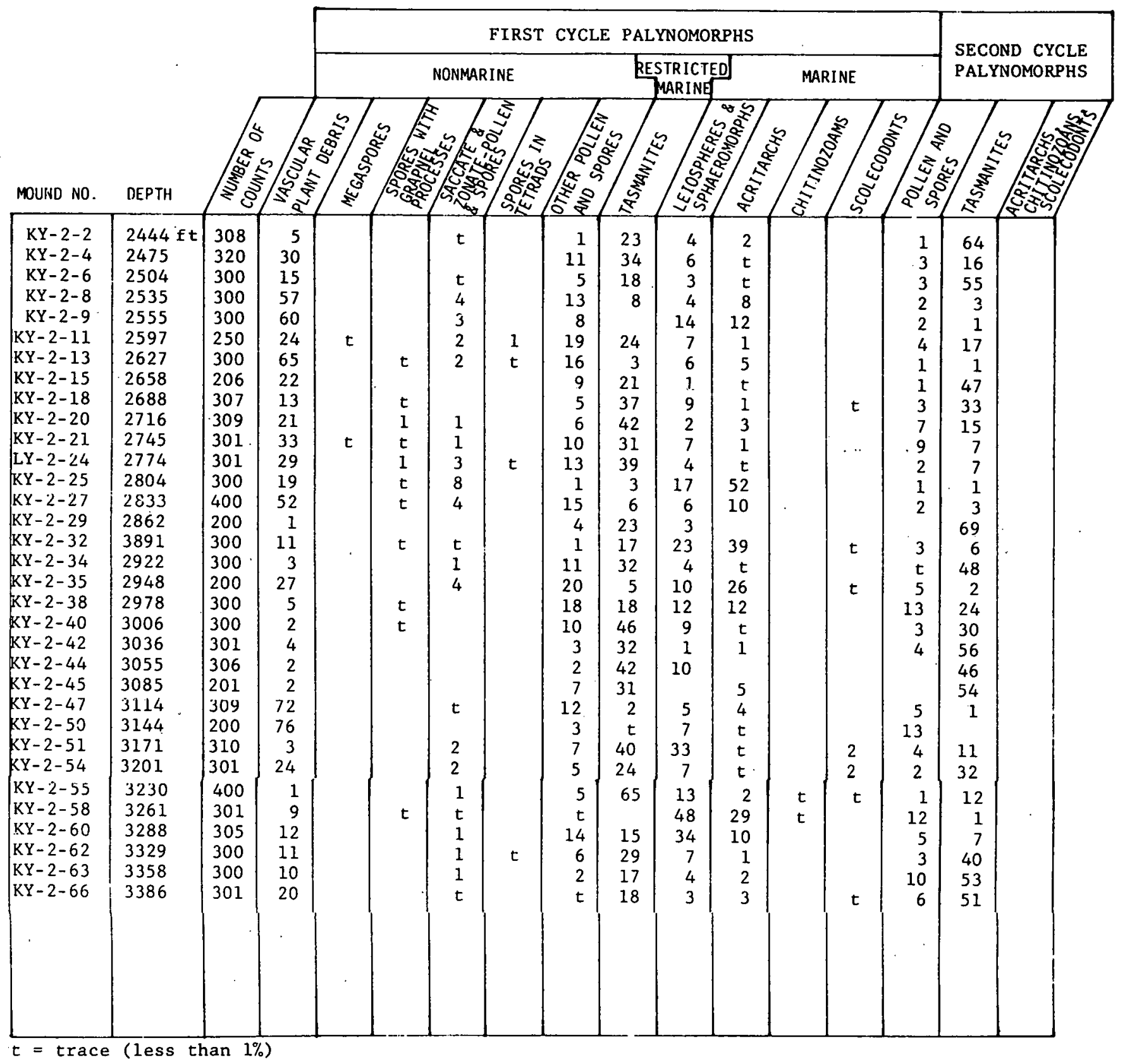


Table 7 - AGE

VA-1. We 11

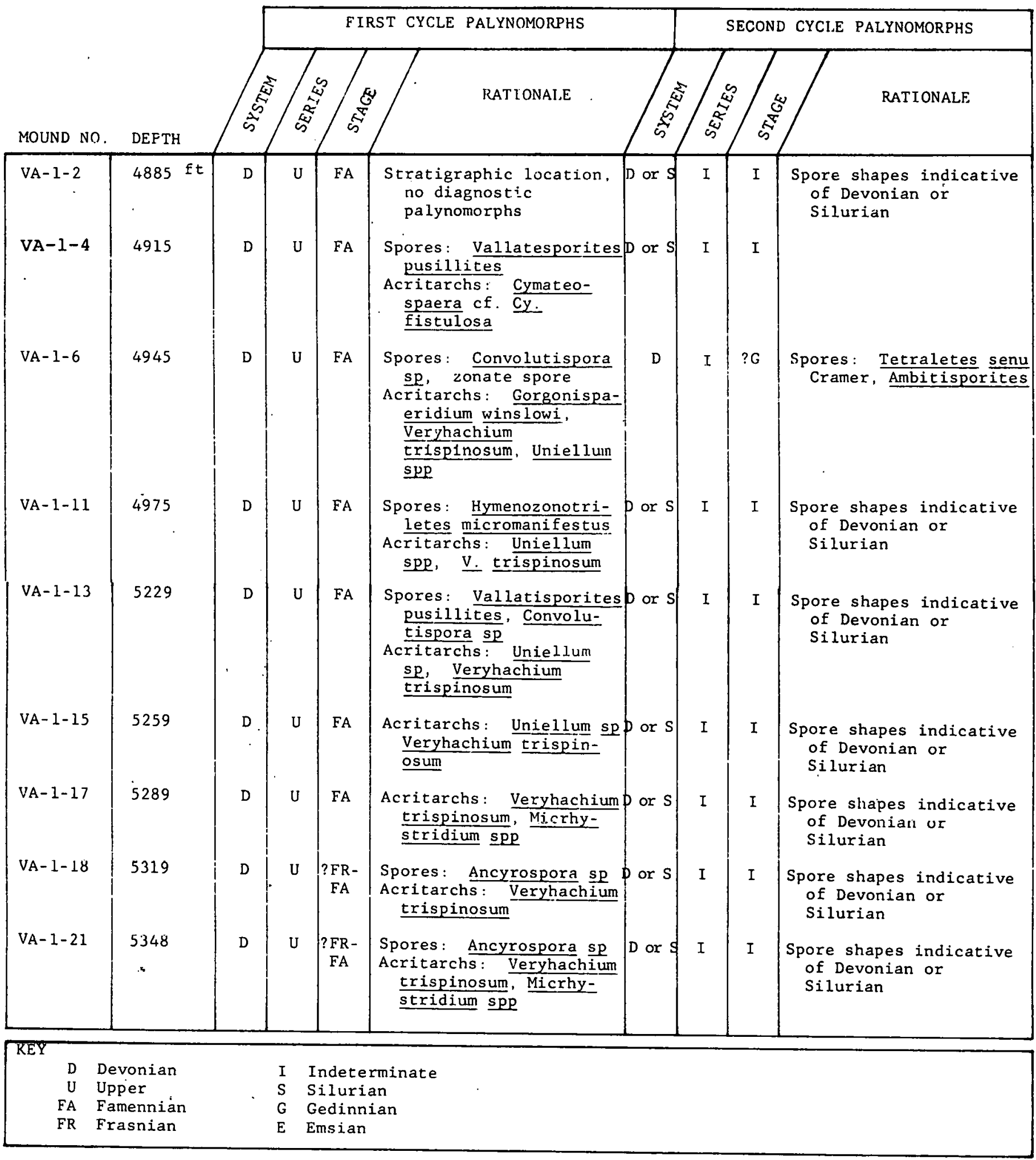


Age

VA-1 Well (Continued)

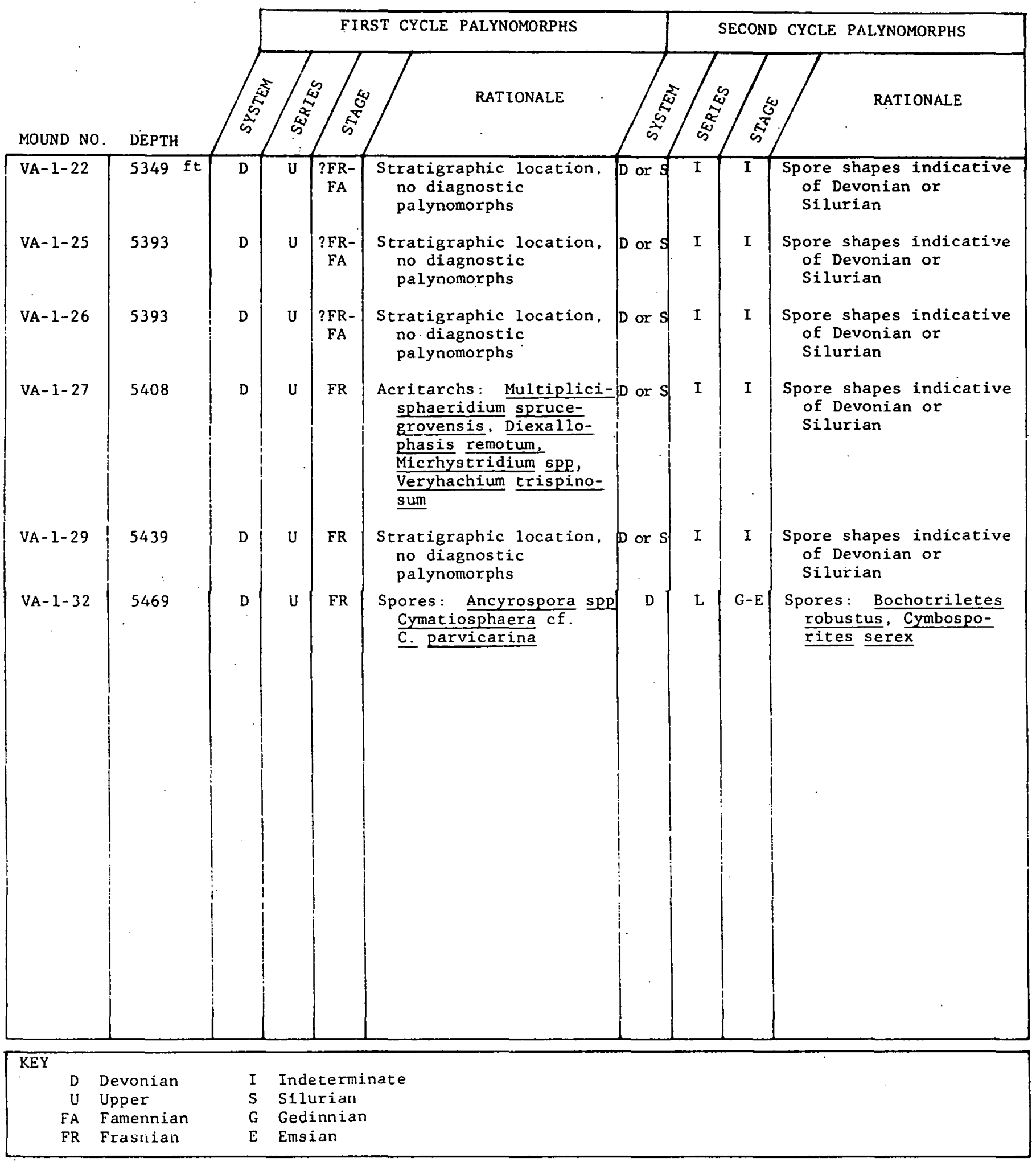



VA-1 Well

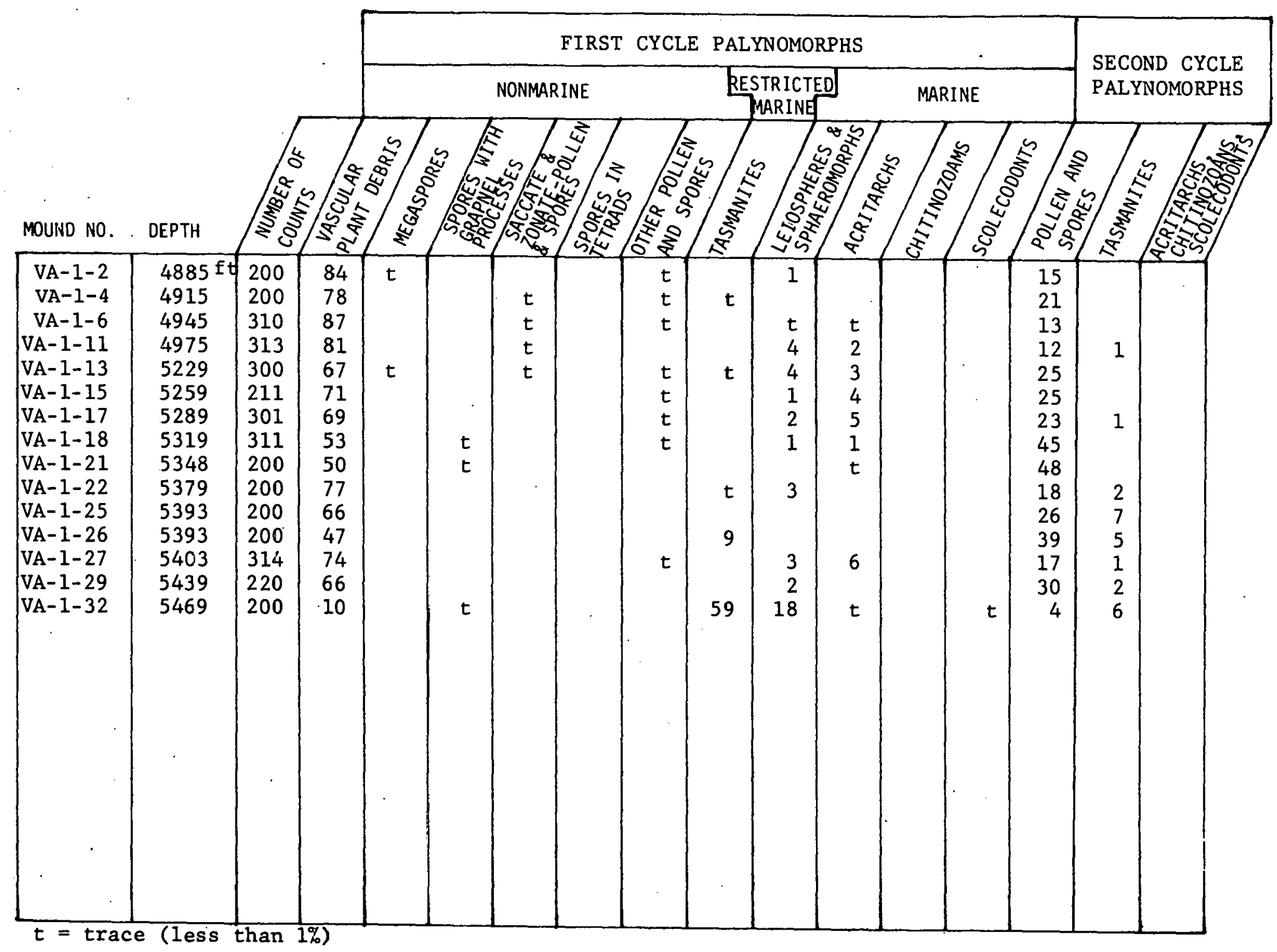


VA-1-2 (depths of 5439 to $4885 \mathrm{ft}$ ) were all deposited in an area subject to large influxes of sediments eroded from earlier Devonian rocks. The abundance of Middle and Lower Devonian spores in those 14 samples is so great that there are only a few Upper Devonian spores in some samples. This dominance of reworked material indicates deposition in an area near the source of the Middle and Lower Devonian plant debris. The second cycle palynomorphs were probably transported either by fluvial systems subsequent to terrestrial erosion or by submarine currents subsequent to submarine erosion.

\section{Conclusions}

The age of the palynomorphs encountered in shales from the four wells studied is Upper Devonian. Although shale thicknesses varied greatly from well to well, the entire Upper Devonian consisting of Frasnian and Famennian subdivisions appears to be present in all wells. Age determinations were based on excellent to poorly preserved palynomorphs. Scolecodonts (teeth of marine worms) were found in some samples but in numbers too small to be usefull for correlation. The most common palynomorphs in the shales are the marine algae Tasmanites spp. whioh are not usable for stratigraphic determinations. Tasmanites spp from these shales are of two kinds: fresh, undegraded fossils which show no evidence of breakdown before their incorporation into the sedillïnls, and other Tasmanites spp (labeled second cycle Tasmanites) which show considerable corrosion and brcakdown of their thick body walls, Some have higher Thermal Alteration Indices (TAI's) than the "fresh" Tasmanites.
There is one common and widespread biofacies dominated by Tasmanites. The section encountered in the 0-1 Well contains abundant Tasmanites and is classified as restricted marine. The Tasmanites-dominated biofacies is found in the basal part of the P-l Well, where somewhat restricted marine conditions are indicated.

The upper sample in the $\mathrm{P}-1$ Well (depth of $2492 \mathrm{ft}$ ) is an example of the biofacies dominated by land plant debris and is completely different from the underlying strata. Shales from the VA-1 Well (VA-1-29 to VA-12) are in the land-plant dominated biofacies. The shales contain large amounts of reworked materials derived from older (Middle and Lower Devonian) strata which had undergone thermal alteration prior to erosion and redeposition. The $\mathrm{KY}-2$ Well contains both of these biofacies plus a third open marine facies not found in the other wells (see cross section). This acritarch dominated biofacies is characteristic of open marine conditions in which acritarchs were diverse and abundant. The algae Tasmanites was not abundant and did not accumulate in the numbers expected in an offshore area of high productivity.

Comparisions of the four wells may be based on the time line arawn at the approximate position of the Fasnian-Famennian boundary. The Dase of Frasnian time (and the base of the Upper Devonian) is near the bottom of al1 four wel1s, but time lines cannot be drawn without location of the youngest Middle Devonian strata. Likewise, the Devonian-Mississippian boundary is probably near the top of all samples from the four wells, but without identification of Lower Mississippian strata, that time line cannot be drawn. 


\section{Acknowledgement}

The authors wish to acknowledge the work of Dr. A. B. Reaugh in preparing the detailed analysis of the specimens.

\section{References}

1. L. R. Wilson and J. Urban, 1962. An incertae sedis palynomorph from the Devonian of Oklahoma. Okla. Geol. Notes $23(1): 16-19$.

2. B. Owens and J. B. Richardson, 1975. Some recent advances in Devonian palynology - a review.' Report of C.I.M.P. Working Group No. $13 \mathrm{~B}$.

\section{Bibliography}

1. Becker, G., Bless, M. J. M., Streel, 1.1., and Thorez, J., 1974. Palynology and Ostracode Distribution in the Upper
Devonian and Basal Dinatian of Belgium and Their Dependence on Sedimentary Facies. Mede. RijksGeol. Dienst. N.S. $25(z): 9-99$.

2. Iardine, S., 1972. Microplankton (Acritarches) et limites stratigraphiques du Silurien terminal au Devonien Superieur. Sept. Congres International de Stratigraphie et de Geologie du Carbonifere, Krefeld, Compte Rendu: Bd. 1:313-323.

3. Wicander, E. R., and Loeblich, A. R., 1977. Organic-walled microplankton and its stratigraphic significance from the Upper Devonian Antrim Shale, Indiana, U.S.A. Paleontographics Abt. B. 160: 129-165. 
Appendix A. 


\section{Description of palynomorphs}

Vascular plant debris: pieces of plant debris > $20 \mu \mathrm{m}$ identifiable by the pattern of the material.

Megaspores: The female reproductive bodies of heterosporous plants; megaspores are generally greater than $200 \mu \mathrm{m}$ in diameter; most commonly found in nearshore marine, deltaic-transitional, or terrestrial environments.

Spores with Grapnel Processes: spores with hook-1ike or grapnel shaped processes; commonly found in transitional environments, especially lagoonal sequences; reached maximum taxonomic diversity in the Frasnian.

Saccate and Zonate Pollen and Spores: pollen and spores which are ornamented by innertube-like structures surrounding the centrai bodies or by sacks which entirely enclose the central-bodies. The structures supposediy aided in air-borne and/or aquatic dispersal of the polien and spores.

Spores in Tetrads: most Devonian spores formed in groups of four cells, tetrads, which would break apart before or during dispersal. When large numbers of tetrads are found, terrestrial or transitional environments are suggested.

Other Pollen and Spores: pollen and spores not included in the preceding four categories; all of terrestrial origin and subject to dispersal by wind or water.

Tasmanites: large (to $300 \mu \mathrm{m}$ ), thick-walled, single-celled marine algae, related to the green allgae chlorophyta

Leiospheres and Sphaeromorphs: very thin-walled marine algae, of spherical shape and variable size.

Acritarchs:. single-celled cysts of marine algae, distinguished by very fine, detailed geometric forms; known only from marine strata.

Chitinozoans: large, ornate, vase-shaped palynomorphs, of unknown affinities; many workers hold the opinion that they were some part of the life cycle of some animal.

Scolecodonts: teeth of marine, polychete worms. 
Appendix B. 
$\cdot 1 \longrightarrow$

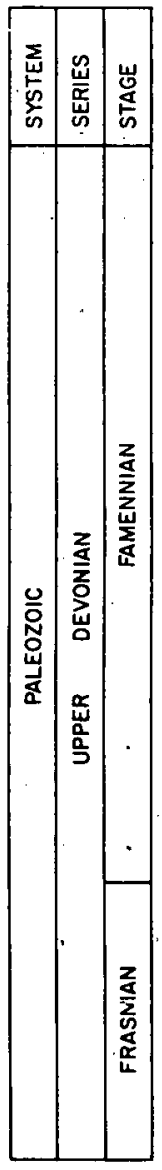

O-I WELL
CHRISTIAN COUNTY, KY.

I

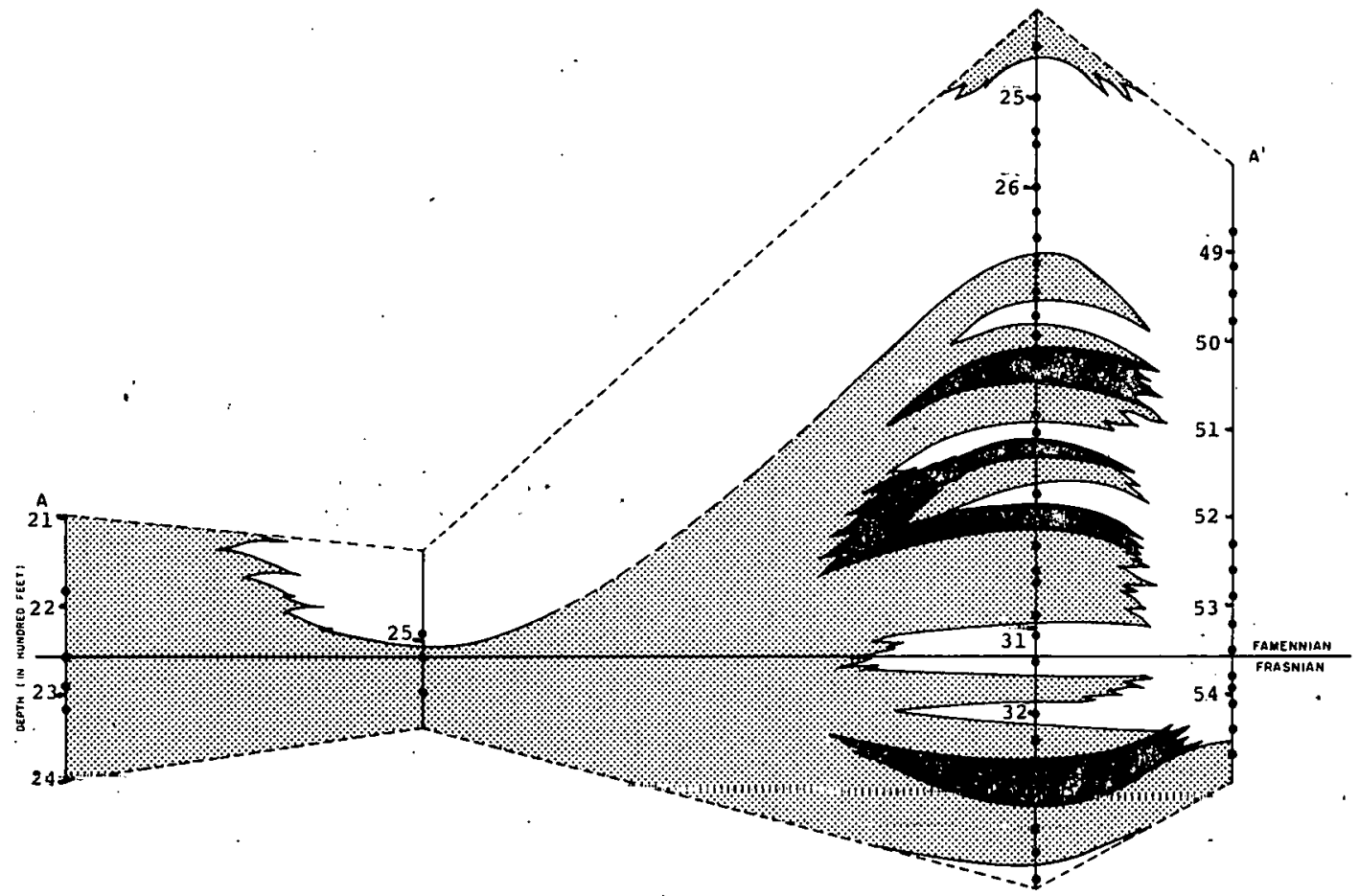

Harine

RESTRICTED MARINE

NONMARINE 

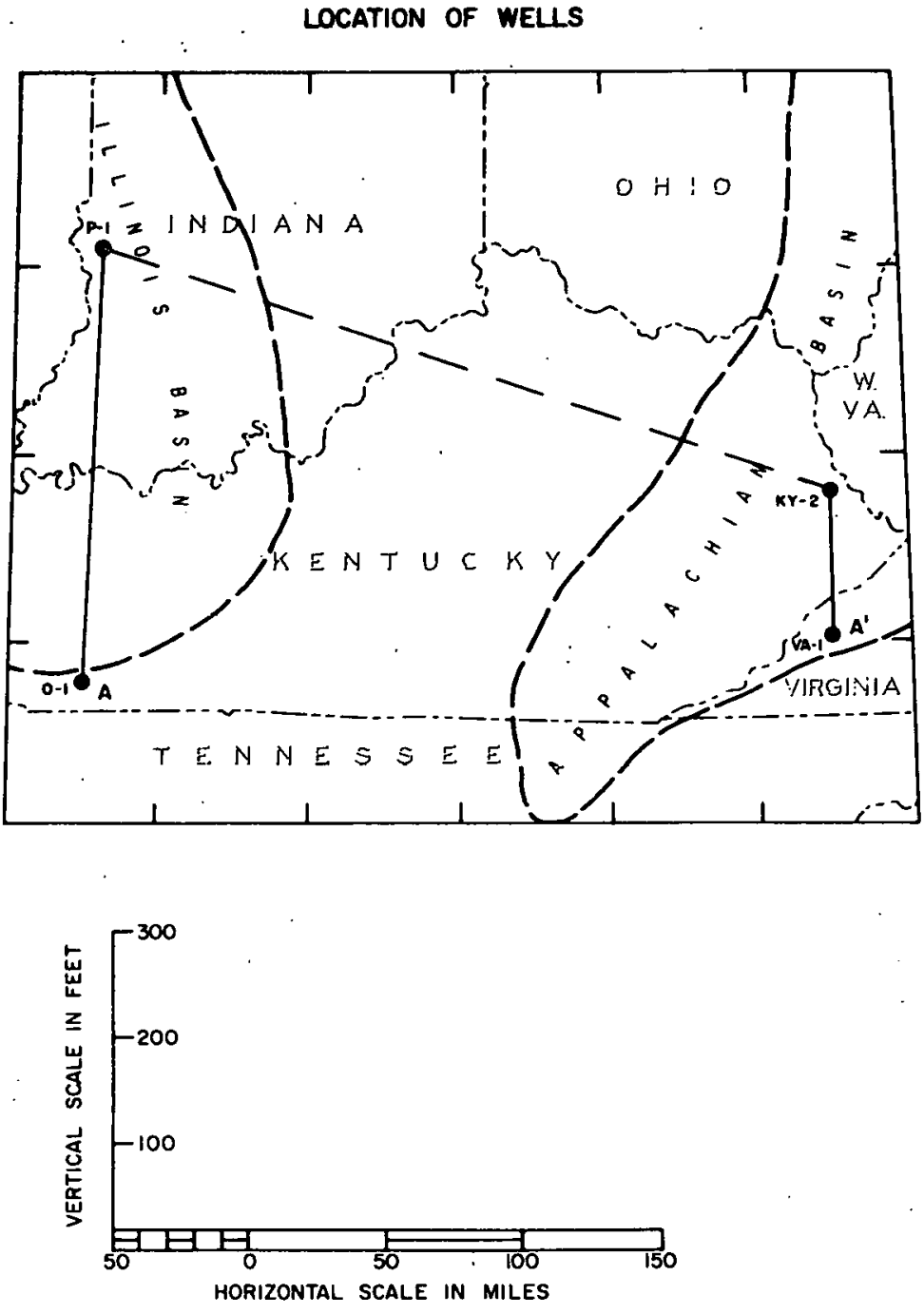

\section{EASTERN GAS SHALES}

REGIONAL DISTRIBUTION OF AGE AND DEPOSITIONAL ENVIRONMENTS SECTION A-A' 


\title{
Distribution
}

\author{
EXTERNAL
}

TIC, UC-92 (230)

Technical Report Library, Monsanto, St. Louis

R. K. Flitcraft, Monsanto Research Corporation

H. N. Hill, DOE/Dayton Area office

S. J. Martin, Geochem Research Inc. (25)

Morgantown Energy Research Center (600)

INTERNAL
W. T. Cave
V. M. Franchetti
C. W. Huntington
L. V. Jones
E. W. Johnson
B. R. Kokenge
R. J. Larson
J. R. McClain
S. W. Nance
W. D. Pardieck
P. W. Seabaugh
H. A. Woltermann
R. E. Zielinski (25)
Document Control
Library (15)
Publications (15) 